\title{
The Effect of Brain Gymnastics on Cognitive Function of Elderly
}

\author{
$1^{\text {st }}$ Noor Cholifah \\ Faculty of Nursing \\ Universitas Muhammadiyah Kudus \\ Indonesia \\ noorcholifah@umkudus.ac.id
}

\author{
$2^{\text {nd }}$ Ratna Nur W \\ Faculty of Nursing \\ Universitas Muhammadiyah Kudus \\ Indonesia
}

\author{
$3^{\text {rd }}$ Yulis Trinowitawati \\ Faculty of Nursing \\ Universitas Muhammadiyah Kudus
}

Indonesia

\begin{abstract}
There were 142 million elderly (8\%) in Southest Asia based on WHO data. Indonesia from 2000-2010, the total elderly has increase from 5.300.000 to 24.000.000. Organ function especially cognitive function belongs to the most common health problem for elderly so far. Moreover, Indonesia becomes the fourth rank after China, India and Jepang. The one way to increase function neurosystem of old people is brain gym because brain gym can improve blood and oxygen to brain. This study is to know the effect of brain Gym on elderly cognitive function at Elderly Health Care of Melati II Candisari village of Purwodadi, Grobogan Regency. This study was quasy experimental research with the approach of pre and post test. The total population were 40 elderly at Health Care of Melati II Candisari, Purwodadi of Grobogan meanwhile the Samples were 36 participants. The data were later tested using paired sample test. The result of this study got $p$ value of 0,000 and $r$ score $-0,746$. There is significant effect of brain gym on elderly cognitive function and there is correlation between brain gym and cognitive Function of Elderly at health care of Melati II Candisari village of Purwodadi, Grobogan Regency.
\end{abstract}

\section{Keywords-Brain, Gymnastic, Cognitive}

\section{INTRODUCTION}

WHO reports that the elderly population in the Southeast Asian Region is $8 \%$ or around 142 million people. In 2050 it is estimated that the elderly population will increase 3 times this year [6]. In 2000 the number of elderly people in Indonesia was around 5,300,000 (7.4\%) of the total population, while in 2010 the number of elderly was $24,000,000(9.77 \%)$ of the total population and in 2020 it was estimated. The population was 60 years old upward it has risen to $28,700,000$ or 11,34 percent (Ministry of Health, 2013). Even in 2020-2025, Indonesia is estimated to be ranked 4th with the structure and number of elderly population after China, India and the United States with life expectancy above 70 years [1].

The Province of Central Java is one of the seven provinces in Indonesia with an aging population. In Central Java, the growth of the elderly is the same as national growth. Data from the Ministry of Social Affairs stated that the number of residents with elderly structures reached 9.39 out of a population of 33,270 people [5]. Along with the increasing number of elderly people will cause various health problems due to a decrease in function in the organ. One of them is the problem of cognitive decline. A study in the UK of 10,255 elderly people over the age of 75 years, showed that the elderly have impaired cognitive function in the central nervous system (45\%) [8].

In 2012 WHO reported that the incidence of cognitive decline in the elderly was estimated at 121 million with a composition of $5.8 \%$ of men and $9.5 \%$ of women. It is estimated that there are 35.6 million people in the world who suffer from Dementia in 2010. 9 countries with the highest number of dementia events in the world in 2010 were China (5.4 million people), United States (3.9 million people), India (3.7 million people), Japan (2.5 million people), Germany (1.5 million people), Russia (1.2 million people), France (1.1 million people), Italy (1.1 million people) ), and Brazil (1 million people) [4].

Based on the Kyoto Declaration data, the prevalence and incidence of dementia in Indonesia ranks fourth after China, India and Japan. In 2000 the prevalence of dementia was 606,100 people and the incidence was 191,400 people. in 2020 it is predicted to increase to $1,016,800$ people with an incident of 314,100 people and in 2050 Dementia will increase to $3,042,000$ with an incidence of 932,000 people [3].

Increased incidence of dementia occurs with age. The prevalence of dementia increases twice every 5 years of age over 60 years. There were $7.2 \%$ of the $24,000,000$ elderly population in 2010 in Indonesia [1]. One way to improve the function of the nervous system in the elderly so that the elderly are able to influence the improvement of cognitive function, namely brain gymnastics. Not only does gymnastics accelerate blood flow and oxygen to the brain, but it also stimulates both hemispheres of the brain to work [2].

From the results of research conducted by Rohmad Agus Wibowo in 2014 in Surakarta, the majority of respondents who experienced cognitive decline or dementia aged 60-74 years were 11 respondents $(53 \%)$ out of $15 \quad$ respondents. In addition to improving cognitive function, brain exercise also functions to reduce stress and improve learning achievement. This was proven by Nurmalita Fitri Dewi 
with her research entitled "The Effect of Brain Gym on Preschoolers Fine Motor Ability in Kindergarten Kartika IV -8 Sumber Sari District of Jember District" obtained results before the exercise of brain 1 person less 21 people enough 6 people good and after doing brain exercise 16 people like 12 people enough.

Researchers are interested in this study because researchers see a phenomenon that occurs in Candisari Village, Purwodadi District, Grobogan Regency, where many elderly people around the researchers experience cognitive impairment. This interest is compounded by research mothers who have entered old age and often forget to turn off the stove. Before researchers determine the place of research, researchers conducted a survey in two places, namely Posyandu Lansia Melati I and Melati II. Where is the result that in Health care of Melati I with 35 elderly members has an age range of 49-59 years and only 3 people who have severe cognitive function with an MMSE value $<21$. While a preliminary study on 15 December 2015 in Posyandu Elder Melati II Candisari Village, Purwodadi, out of 20 elderly people by examining the cognitive function of the elderly using MMSE (Mini Mental Status Examination) obtained normal cognitive function results of 2 people, 8 people with mild dementia and mild dementia 10 people weigh.

Based on the results of preliminary research shows the number of elderly with severe dementia in the elderly posyandu as many as 10 elderly from 20 elderly or $50 \%$ of the sample, the average MMSE value of 10 .

\section{RESULT}

Characteristics of Respondent

\begin{tabular}{|c|c|c|}
\hline Ages & Frequency & $\begin{array}{c}\text { Percentage } \\
(100 \%)\end{array}$ \\
\hline$<70$ years old & 22 & 61,1 \\
\hline$>70$ years old & 14 & 38,9 \\
\hline Total & 36 & 100 \\
\hline
\end{tabular}

Based on table I shows that the most respondents who are elderly have age <70 years that is 22 people $(61.1 \%)$ and those who have the least age 70 years as many as 14 people $(38.9 \%)$.

TABLE II. FREQUENCY DISTRIBUTION BASED ON GENDER BASED ON TABLE 1.2, IT IS SHOWN THAT MOST OF THE ELDERLY GENDERS ARE FEMALE (23 (63.9\%) AND A SMALL NUMBER OF MALES ARE 13 (36.1\%).

\begin{tabular}{|c|c|c|}
\hline Jenis Kelamin & Frequency & Percentage $(\%)$ \\
\hline Laki-Laki & 13 & 36,1 \\
\hline Perempuan & 23 & 63,9 \\
\hline Total & 36 & 100 \\
\hline
\end{tabular}

TABLE III. FREQUENCY DISTRIBUTION BASED ON WORK

\begin{tabular}{|l|l|l|}
\hline \multicolumn{1}{|c|}{ Pekerjaan } & \multicolumn{1}{|c|}{ Frequency } & $\begin{array}{c}\text { Percentage } \\
(\%)\end{array}$ \\
\hline Buruh Tani & 10 & 27,8 \\
\hline Ibu Rumah Tangga & 6 & 16,7 \\
\hline Petani & 17 & 47,2 \\
\hline Swasta & 3 & 8,3 \\
\hline Total & 36 & 100 \\
\hline
\end{tabular}

Based on table III shows that the most elderly work as farmers, as many as 17 people $(47.2 \%)$ and the least as private employees, as many as 3 people $(8.3 \%)$.
A. Research Design

The research used was Quasi Experiment. Quasi experiment is a study that tests an intervention in a group 列 he research design used is quantitative with pre and Elderly Candisari Village Purwodadi District Grot District, the elderly intervention group would do brain gymnastics and the control group would carry out reminsence activities

The population in this study were all the elderly in the village of Candisari, Purwodadi Subdistrict who were ef the elderly Posyandu, consisting of 40 amples to be used in this study were 36 people in which people were the intervention group and 18 were the

\section{Data Colleting and Analysis} observation sheet, demographic analysis used was the Paired Sample T-Test, Independent Sample T-Test and Kendall's Tau-b. 
TABLE IV. FREQUENCY DISTRIBUTION BASED ON EDUCATION

\begin{tabular}{|l|c|r|}
\hline Education & Frequency & Percentage (\%) \\
\hline SD & 23 & 63,9 \\
\hline SMP & 13 & 36,1 \\
\hline Total & 36 & 100 \\
\hline
\end{tabular}

Based on table IV shows that the most elderly took the latest education at elementary school as many as 23 people
$(63.9 \%)$ and the least took education at the end of junior high school as many as 13 people (36.1\%).

TABLE V. COMPARISON OF COGNITIVE FUNCTIONS BEFORE AND AFTER BRAIN EXERCISE IS GIVEN IN THE INTERVENTION AND CONTROL GROUPS

\begin{tabular}{|l|c|c|c|c|}
\hline Groups & $\mathrm{N}$ & Mean & SD & Pvalue \\
\hline (Intervention group) & & & & \\
Before intervention & 18 & 19,33 & 2,114 & 0,000 \\
After intervention & 18 & 23,33 & 2,744 & \\
\hline (Control group) & & & & \\
Before intervention & 18 & 21,17 & 2,383 & 0,695 \\
Without intervention & 18 & 21,28 & 2,396 & \\
\hline
\end{tabular}

After the Paired Sample Test, the difference between the average Cognitive Function comparison in the intervention group was 0,000 , the difference in the Cognitive Function comparison in the control group was 0.695 . And obtained $\mathrm{p}$ Value of $0,000<\alpha(0,005)$. Thus Ha failed to be rejected and Ho was rejected, which means there is an Effect of Brain Gymnastics on Elderly Cognitive Function in Posyandu Elderly Melati II of Candisari Village, Purwodadi District, Grobogan Regency.

\section{DISCUSSION}

In accordance with the general objective in this study, it is to find out the influence of brain exercise on the cognitive function of the elderly in Posyandu Lansia Melati II Candisari Village, Purwodadi District, Grobogan Regency. In this study respondents who experienced a decline in cognitive function given brain exercise showed a significant increase in the average cognitive function before and after administration of brain exercise. While some respondents who experienced a decline in cognitive function were not exercised but performed reminsence, the results did not show a significant change in the average cognitive function before and after treatment. Prior to brain exercise treatment in the elderly, the cognitive function group was 18.44 , the median value was 18.00 , the mode value was 18 , the standard deviation was 2.479 , the minimum value was 15 and the maximum value was 24 .

Neurodegenerative diseases often occur in older people, probably because in the aging process there have been many neuronal disorders. Cells or tissues that are still young are equipped with the ability to renew themselves, maintain their structure and function, withstand injury and are able to repair the damage that they cause. In the aging process this ability decreases and disappears gradually. Some neurodegenerative diseases are generally associated with this disorder.

Many factors affect the integrity of the central nervous system at the age of more than 50 years, because it needs regular checks on memory and cognitive functions such as MMSE and GDS [10].
Respondents in this study were clients who experienced cognitive decline in Posyandu Lansia Melati II Candisari Village, Purwodadi District, Grobogan Regency. Most $(61.1 \%)$ of respondents were $<70$ years old. The lowest age of the elderly is 62 years.

The older a person is, the better the process of mental development, but at a certain age, increasing the process of mental development is not as fast as when he was a teenager. Memory will decrease because it is influenced by age [11].

After brain exercise, the average cognitive function becomes an intervention value of 23.50 , a median value of 23.00, a mode value of 23 , a standard deviation of 2.618 , a minimum value of 18 and a maximum value of 27 .

The Expert Staff of the Indonesian Health Ministry's Elderly Working Group, Yuda Turana, said that the elderly often forget their brains, even though they usually do a full body health test. Though dementia or senility problems associated with brain function are very vulnerable to the elderly. However, now many have developed brain gymnastics. Brain gymnastics is a low-impact exercise that pays attention to aspects of balance, memory, and coordination of the brain, including movement functions [6].

This study was conducted brain exercise on 18 elderly in the intervention group. Researchers teach clients how to do brain exercises in accordance with existing operational standards. Besides being able to improve the cognitive function of brain exercise can also facilitate the flow of brain oxygen. The purpose of brain exercise is to slow senility, relieve stress, increase concentration, make emotions calmer.

In addition to the 18 respondents in the intervention group, the authors also made a comparison with 18 respondents in the control group who were not treated with brain exercise. To fulfill a sense of justice, the control group was given communication interventions such as reminsence. After the intervention group was given treatment, and the control group was not given treatment it 
was obtained that the cognitive function of the intervention group was more significant than the control group.

After exercising the elderly's cognitive function brain exercises have improved in almost every aspect, this is evidenced by the increase in the value of MMSE peraspek that can be seen from the minimum and maximum values of respondents in each aspect.

In the aspect of orientation the minimum value before brain exercise 4 was obtained by 1 respondent (5.6\%), after brain exercise was done the minimum value was 6 which was obtained by 1 respondent $(5.6 \%)$. While the maximum value before doing brain exercise 9 was obtained 1 (5.6\%), after brain exercise the maximum value was also 9 but obtained 5 people $(27.8 \%)$.

In the attention aspect the minimum value before brain exercise 2 was obtained by 1 respondent $(5.6 \%)$, after brain exercise was done the minimum value was 3 which was obtained by 6 respondents $(33.3 \%)$. While the maximum value before brain exercise 4 was obtained $10(55.6 \%)$, after brain exercise the maximum value of 5 was obtained 4 people $(22.2 \%)$.

In the aspect of registration the minimum value before brain exercise 1 obtained 4 respondents $(22.2 \%)$, after the exercise of the brain exercise the minimum value was 2 obtained by 7 respondents $(38.9 \%)$. While the maximum value before brain exercise 3 was obtained 7 (38.9\%), after brain exercise the maximum value of 3 was obtained 11 people $(61.1 \%)$.

In the aspect of registration the minimum value before brain exercise 1 obtained 4 respondents $(22.2 \%)$, after the exercise of the brain exercise the minimum value was 2 obtained by 7 respondents $(38.9 \%)$. While the maximum value before brain exercise 3 was obtained 7 (38.9\%), after brain exercise the maximum value of 3 was obtained 11 people $(61.1 \%)$.

In the aspect of remembering the minimum value before brain exercise 1 was obtained by 1 respondent $(5.6 \%)$, after brain exercise was done the minimum value was 2 which was obtained by 10 respondents $(55.6 \%)$. While the maximum value before brain exercise 3 was obtained 4 $(22.2 \%)$, after brain exercise the maximum value of 3 was obtained 8 people $(44.4 \%)$.

In the aspect of language the minimum value before brain exercise 4 was obtained by 2 respondents (11.1\%), after brain exercise was done the minimum value was 6 which was obtained by 3 respondents $(16.7 \%)$. While the maximum value before brain exercise 8 was obtained 1 $(5.6 \%)$, after brain exercise a maximum value of 9 was obtained by 2 people $(11.1 \%)$.

The difference in the average cognitive function there is a significant difference between the intervention group and the control group ( $p$ values: 0,000 and $\alpha: 0.695$ ). Based on the research results obtained in this study it appears that brain exercise has a significant effect on cognitive function in the elderly.

The results of this study are in accordance with the theory which states that brain exercise is one of the nonpharmacological therapies to improve cognitive function. Six brain brain therapy is an easy therapy that does not require special equipment and can optimize the abilities that still exist [9].

This is reinforced by research Ida Untari with the title Effectiveness of Exercise Preventing Senile Up Brain's Game Against Improvement in Memory in the Elderly. The research instrument uses the Short Portable Mental Status Questionaire (SPMSQ) to measure senility and audiovisual media for Up Brain'sGame gymnastics. Exercise training is done 3 times a week for one month. Data analysis was tested with t-test. The results of this study, there is a positive effect on exercise training to reduce memory recall to be better with a value of $\mathrm{p}=0,000$.

Unlike the case with research conducted by Yulistina in 2019 with the title Effectiveness of Brain Vitational Gymnastics on Cognitive Function of Elderly with Early Stage Dementia. From the results of the Paired T-Test, the results of the treatment group showed a value of $p=0.03$ which indicates a significant influence on brain vitality training on improving cognitive function. While the results of the Independent Samples T-test obtained $p=0.06$, indicating that there was no significant difference in the effect of vitality brain exercises on cognitive function between the treatment group and the control group. Thus it can be concluded that the brain vitality exercise was effective to improve and maintain cognitive function in elderly with early stage dementia. Kendall's tau $-\beta$ test results obtained the value of $\mathrm{r}$ (continuity correlation) of .746. This, shows that the value of $r$ is in the range 0.60 0.799 (correlation has a strong closeness). The value of $p$ value, 000 has a Sig value $<0.05$ then $\mathrm{H} 0$ is rejected, which means "there is a significant relationship / influence between brain gymnastics with cognitive functions"

This cognitive increase is influenced by movements performed in the brain vitality gymnastics that stimulate the cooperation of the cerebral hemispheres and between parts of the brain. If the function of the parts and cerebellum increases, it will cause increased blood flow to the brain as a source of nutrition. When brain nutrition is fulfilled, the learning process will be better so that program intake can be processed through the center of thought (memory and intellectual). The more good and good intake of programs that occur in the learning process, the more branching nerve cell lines are formed. This can increase the cooperation of nerve cells and multiply the formation of interconnected cell lines so that they can improve memory (memory) and can affect intelligence, intellectual and cognitive functions [9].

\section{CONCLUSION}

In short, based on the results of research and discussion that has been described in the previous section, several conclusions can be drawn including: 1. There is an influence of brain exercise with the cognitive function of the elderly in Posyandu Lansia Melati II Candisari Village Purwodadi District Grobogan in 2019 in the intervention group significant value of 0,0002 . There is a relationship between brain exercise and cognitive function in Posyandu Melati II Candisari Village, Purwodadi District, Grobogan Regency in 2019 because the $r$ value of -0.746 is obtained. 


\section{ACKNOWLEDGMENT}

This research was supported/partially supported by Muhammaiyah University of Kudus. I really thank head of research and publication department of UMKU for assistance with particular technique, methodology and for comments that greatly improved the manuscript.

\section{REFERENCES}

[1] BPS, B. P. (2013). Jumlah Lansia Years old 200-2010. Jakarta: badan Pusat Statistik.

[2] Dennison. (2008). Buku panduan Lengkap Brain Gym Senam Otak. Jakarta: Grasindo.

[3] Dissease, I. A. (2006, Desember 15). Dimensia di Kawasan AsiaPasifik. hal. http://www.Alzheimeir.org.au.
[4] Fatimah. (2010). Merawat Manusia Lanjut Usia Suatu Pendekatan Proses Keperawatan Gerontik. Jakarta: Trans Info Media.

[5] Ivan. (2012, Desember 15). Jumlah Lansia akan Terus Bertamabah.

http://kedaulatanrakyat.co.id/read/14969/jumlahlansiaakan terusbertambah.

[6] Nugroho, W. (2008). Keperawatan Gerontik dan Geriatrik. Jakarta: EGC.

[7] Stanley, M. (2006). Keperawatan Gerontik. Jakarta: EGC.

[8] Suhartini. (2009). Penyusunan Olahraga Terapeutik untuk Lansia. Jakarta: Grasindo.

[9] Sundet, R.-A. \&. (2008). Factors Assosiation with Chaging Cognitive Function In Order Adults. Journal of Geriatric .

[10] Stanley. (2007). Buku Ajar Keperawatan Gerontik. Jakarta: EGC.

[11] Waston. (2008). Perawatan pada lanjut Usia. Jakarta: EGC 